\title{
Barriers for Renewable Energy Technologies diffusion: empirical evidence from Finland and Poland
}

\author{
Oskar Juszczyk ${ }^{1, *}{ }^{*}$, Juliusz Juszczyk ${ }^{2}$, Sławomir Juszczyk ${ }^{2}$ and Josu Takala ${ }^{1}$ \\ 1 Department of Production, School of Technology and Innovations, University of Vaasa, 65101 Vaasa, \\ Finland; josu.takala@uwasa.fi \\ 2 Institute of Economics and Finance, Faculty of Economics, Warsaw University of Life Sciences - SGGW, \\ 02-787 Warsaw, Poland; juliusz_juszczyk@sggw.edu.pl (J.J.); slawomir_juszczyk@sggw.edu.pl (S.J.) \\ * Correspondence: oskar.juszczyk@uwasa.fi
}

\begin{abstract}
A harmful impact of climate change and global warming has concerned various sectors of the international community. Numerous energy policies aiming at climate change mitigation have been implemented on a national and global scale. Renewable Energy Technologies (RET) play a critical role in enhancing sustainable solutions that significantly limit greenhouse gases (GHG) emissions. Such innovative technologies can facilitate energy transition through providing e.g. energy security, sustainable development, or effective usage of indigenous resources. However, the commercialization of RET becomes extremely challenging. The barriers can be of a different nature, although in this study the focus has been put on socio-economic and regulatory issues. In fact, there is ample evidence that energy policies play a central role in supporting renewables adoption. It is also claimed that RET require the whole ecosystem to support their successful diffusion. In this study, we explore multifarious barriers for a widespread RET diffusion in two European Union countries: Finland and Poland, indicating the most common barriers existing in the literature as well as analyzing major bottlenecks in the viewpoint of renewable energy companies' executives. We also present statistics of the most commonly used RET in these countries in order to express the diffusion issues more appropriately. The research shows that inflexible, ineffective, and excessive regulatory frameworks, limited financing options as well as insufficient level of societal awareness have been seen as the main bottlenecks for RET diffusion in both countries. The outcomes of this study provide useful insight for the researchers in the energy transition field as well as practical managerial and regulatory implications aimed at overcoming these challenges.
\end{abstract}

Keywords: renewable energy; technology diffusion; innovation management; energy policy; sustainable development; European Union (EU); barriers

\section{Introduction}

The world's current geopolitical landscape is struggling with numerous problems. We are witnessing unprecedented issues, primarily the COVID-19 global pandemic, which has dramatically shifted the reality we exist in. Moreover, the challenges that bother the international community the most already from several decades are still present, such as overpopulation, 'consumerism', raising levels of socio-economic inequalities, military conflicts, or - especially important in this study - air pollution. The adverse impact of climate change is causing multifarious constraints. Global warming is deteriorating the natural resources of the planet, which causes massive human and animal migrations as well as the distinction of different species, overflooding, ozone layer vanishing, melting and greying of the polar zone, etc. It is already common knowledge that action from different sectors of society needs to be taken immediately if we wish to protect our planet from the forecasted catastrophic consequences [1].

One of the processes that would significantly improve the quality of life on our planet, is to limit greenhouse gases emission by implementing environmentally-friendly technology solutions, such as circular economy or renewable energy sources [2]. 
Renewables, as the name suggests itself, are free, constantly available, and coming from natural resources - therefore, it is in common sense to implement such technologies not only to save costs but most importantly, to save our planet. However, the implementation of renewable energy technologies (RET) into the countries' energy mixes is a complex, multidimensional, and also problematic process. Such a socio-technical transition requires e.g. an alteration in current technological and regulatory regimes, time- and cost-consuming infrastructural investments, introduction of supportive energy policies, or awarenessraising actions within the society [3].

This paper aims to present the most commonly used renewable energy sources in two European countries: Finland and Poland. After such determination, we will focus on the renewables with the most share in order to examine the specific barriers to their implementation. We will do so by presenting the most popular barriers from the literature review to also put them into categories. Next, we will reveal the results of our empirical analysis. It is important to note here that, for the purpose of this study, the focus has been put on the socio-economic and regulatory barriers for a successful RET diffusion. The authors' team consists of researchers from two Universities in Finland and Poland. Having a long-lasting scientific collaboration experience, we decided to compare the multi-dimensional conditions for the development of innovative, renewable energy technologies in these two countries. We believe that such a comparison will provide useful implications for the interest groups coming from different sectors of both Finnish and Polish society.

The differences between these two countries are meaningful and relatively easy to notice even at a first glance. Finland is one of the world's most innovative countries, leading in many global R\&D and sustainability rankings [4]. In the case of the economy, the share of domestic capital in total GDP generation is astonishingly high, making the country relatively close to the state of autarky. Moreover, as a Nordic country, the archetype of admiration and cultivation of nature is deeply rooted in Finnish culture [5]. Therefore, the circumstances for enhancing sustainable practices are strongly favorable: where the level of societal willingness to adopt renewables is very high, and the government is providing a supportive regulatory framework, businesses focused on developing RET are emerging more eagerly and have more chances to prevail [6].

Poland, on the other hand, is still categorized as a developing country. Even though the annual GDP growth rate is steadily fast, innovative energy investments are forced to compete with the conventional solutions. There are growing numbers of especially solar PV and wind turbines installations, however, the country's energy mix is strongly coaloriented. The mining industry has been important for the Polish economy for many decades, and still is [7]. It is located mainly in the Silesia region; therefore, such a socio-technological transition would require systemic change that could create new opportunities for all the interest groups coming from this sector. The other important factors slowing the adoption of renewables in Poland is the cost of the infrastructural change required to enhance RET development and general reluctance to change the current situation within the society [8]. However, there are many national and regional energy policies, activist movements, and other mechanisms that aim to support sustainable energy generation and set ambitious targets for the future.

\section{Literature review}

The successful commercialization of innovative technologies is highly reliant on the technology, regulatory, and market-related aspects. This process becomes even more troublesome when the technology in question is highly innovative and requires an adjustment in current structures. Renewable Energy Technologies (RET) can be classified as disruptive [9], and therefore require substantial investments with usually a relatively long payback time, have significant dependence on the available infrastructure and regulatory support, and are often challenged by unpredictable market conditions [10].

\subsection{A central role of energy policies}


The literature firmly supports the claim that supportive regulatory frameworks are a key factor for the renewable energy markets development, suggesting that this factor is preliminary, thus even more critical than the economic, managerial, or commercial excellence of the companies [11]. Governments, often legally bonded by numerous international energy policies, are nowadays more eager to enhance sustainable technologies in order to fulfill the targets of such regulations [12]. The common efforts of the international community to combat the deteriorating impact of global warming have resulted in the introduction of the United Nations' Paris Agreement during the COP21 global summit in 2015. The goals for 2020 were so-called ' $3 \times 20 \%$ ' which corresponded to increasing the share of renewables and energy efficiency by $20 \%$ as well as reducing the CO2 emissions by $20 \%$, compared to 1990 realities [13]. UN organizes following climate change conferences updating the targets and measures for a climate-friendly world - with a most recent one, COP26, organized in November 2021 in Glasgow, Scotland. The current targets for 2030 within the European Union aim at 40\% greenhouse gases (GHG) emissions reduction, compared to the 1990 situation, as well as 32\% share of global renewable energy sources and 32,5\% global energy efficiency [14]. Furthermore, the European Commission has implemented the strategy for making Europe climate-neutral by 2050, which imposes 80-95\% GHG emissions cut in comparison to 1990 as well as increasing the level of renewables to 50\% [15]. These two major policies play a lead role in keeping the global temperate increase below $2{ }^{\circ} \mathrm{C}$ with the aim to maintain it at $1.5^{\circ} \mathrm{C}$.

In addition to the strictly legal and image-creating aspects, renewables-enhancing national policies are created when the long-lasting potential benefits coming from RET usage are forecasted. Importantly, renewables can provide e.g. energy security, sustainable development, or proficient use of the country's indigenous resources [16]. Moreover, RET can help to diversify the energy supply, significantly decrease the dependency on imported fuels or create niche markets. Governments, realizing these multifarious benefits coming from the renewables' adoption, include such energy sources in their national energy strategies, and often develop and publish well-suited Renewable Energy Action Plans in order to reflect the global requirements on the country-specific level, and to generate a roadmap for implementing environmentally-friendly technologies in a realistic, efficient and sustainable way.

\subsection{The importance of socio-economic conditions}

Studies conducted by Shakeel et al. [10] and Peura et al. [17] claim that the limited financing options, market uncertainty, infrastructural support, internationalization challenges, or market-driven technology development are some of the main hindrances causing the slow commercialization of renewable energy technologies in Finland. As can be concluded, the challenges for the companies developing are multidimensional and RET require the whole ecosystem to enhance their diffusion. It is argued that apart from the supportive policy framework, technology push and market pull effects are perceived as key factors for a successful sustainable energy innovation adoption [18]. A relatively high level of social awareness is a crucial aspect, as various bottom-up initiatives aiming at improving the overall quality of life by introducing more and more environmentallysound solutions can be raised by, inter alia, using the market pull mechanisms to bring the sustainable products into the economy.

Similarly, the ecologically-conscious stakeholders often require the managers to follow the triple-bottom-line approach to generate economic, environmental, and societal value for their portfolio companies $[19,20]$. Such business conduct styles cause an important change from the strictly short-term profit orientation practices, widely performed previously. However, it is important to note that the fact of being eco-friendly and efficient will not act as a sort of a magic wig and automatically get and sustain the RET a reasonable market share as the end-products generated from such technologies are often costlier, and consequently - uncompetitive with the conventional solutions. It is in common economic knowledge that for the customers, the cost is often a critical variable. Nevertheless, 
according to Owen [21], the RET will become cost-competitive if the so-called 'externality costs' are considered, and they stand for the costs of the ecological damage inevitably related to the energy production from fossil fuels. Therefore, it can be concluded that the higher level of the environmental awareness within all the sectors of society, the bigger chances for the RET of being successfully commercialized.

Moreover, to support the importance the societal conditions, it is also important to mention the Technology Acceptance Model (TAM) developed by Fred Davis in 1989, which is a theory that models the acceptance and utilization processes within the endusers of new technology [22]. According to this theory, the decision of the end-user is influenced by numerous factors, and mainly by 1) perceived usefulness, further defined as "the degree to which a person believes that using a particular system would enhance their job performance"; and by 2) perceived ease-of-use, which can be explained as "the degree to which a person believes that using a particular system would be free from effort".

\subsection{Major RET diffusion barriers}

The literature review provides plentiful examples of different barriers to a successful RET adoption. Primarily, Owen mentioned externality costs as major market barriers, which are often not included in the business strategies [21]. In his analysis based on the International Energy Agency's report, he provides further commonly experienced market barriers in the energy area, as can be seen in Table 1.

Table 1. Examples of market barriers to RET diffusion. Developed based on [21].

\begin{tabular}{|c|c|c|}
\hline Market barrier & Characteristics & Solutions \\
\hline $\begin{array}{l}\text { Uncompetitive electricity prices \& } \\
\text { price distortion }\end{array}$ & $\begin{array}{l}\text { Externality costs and economies of } \\
\text { scale not yet included }\end{array}$ & $\begin{array}{l}\text { Awareness-raising actions, } \\
\text { Subsidies \& taxes customized }\end{array}$ \\
\hline Insufficient knowledge & $\begin{array}{l}\text { Information about the technologies } \\
\text { need to be widely available }\end{array}$ & $\begin{array}{l}\text { Standardization \& labeling } \\
\text { Quality certificates }\end{array}$ \\
\hline Transactional costs & $\begin{array}{l}\text { Administration cost, green certifica- } \\
\text { tion, permits, and usage }\end{array}$ & $\begin{array}{l}\text { Information \& calculation systems } \\
\text { for the decision-makers }\end{array}$ \\
\hline Financial risk & $\begin{array}{l}\text { Long payback time, high entry } \\
\text { threshold, limited financing, sunk } \\
\text { costs }\end{array}$ & $\begin{array}{l}\text { Live cycle cost analysis } \\
\text { External funding options }\end{array}$ \\
\hline Inappropriate regulations & $\begin{array}{l}\text { Obsolete energy policies, often sup- } \\
\text { porting traditional solutions }\end{array}$ & Future-oriented energy plans \\
\hline Conservative markets & $\begin{array}{l}\text { Inadequate split of benefits between } \\
\text { different stakeholders }\end{array}$ & $\begin{array}{l}\text { Market restructuration and democra- } \\
\text { tization }\end{array}$ \\
\hline Technology-related & $\begin{array}{l}\text { Obsolete infrastructure, technologi- } \\
\text { cal know-how required }\end{array}$ & $\begin{array}{l}\text { Grid modernization, commercializa- } \\
\text { tion aspects, business-oriented engi- } \\
\text { neering }\end{array}$ \\
\hline
\end{tabular}

As renewable energy sources are diversified, and the technology diffusion process is multifaceted and complex, scientists consider diverse concrete renewable energy technologies e.g. solar PV [23], biogas [24,25,26], or wind energy [27,28]. Furthermore, authors often scrutinize it by basing on particular determinants or perspectives of various interest groups as well as perform case studies on specific geographical areas. For example, some authors investigated the bottlenecks of RET implementation from the customers' viewpoint $[29,30]$, whereas others reflect this issue from the investors' perspective [31]. Interestingly, a study led by Lucchi provides a conceptual framework for the integration of solar PV on the heritage sites, and they determined three major criteria to consider by governments during the planning process, and these are: "localizing", linked to location; "qualitative", primarily suggesting the smallest possible impact the environment; and "quantitative", determined by technology performance and economic aspects. The study concludes with the claim that the RET require well-defined energy policies, simplified 
standards, skilled personnel, and large amount of existing leading examples to lead the way for the others to ensure their widespread diffusion [32].

Authors like Ruggiero, Davis, or Jung examined the societal awareness and technology acceptance as well as 'willingness-to-pay determinants [22,33,34]. Studies led by Popp and Tsoutsos provide insight on the technology diffusion phenomena through the lens of energy sustainability $[35,36]$. Nonetheless, the vast majority of research on renewable energy adoption concentrates on energy policies' analysis [7,37,38,39]. However, in this study, the holistic approach has been chosen to present the socio-economic and regulatory barriers of the diffusion of different RET in general, which follows a method previously used in the literature that serves to provide the overview of the whole renewable energy industry, and not to focus on the specific technology $[40,16,10]$.

\section{Methodology}

In this study, we adopt a mixed methodology of policy analysis, literature review, and cross-case qualitative case study. We have conducted semi-structured interviews with a total number of 13 executives representing 12 RET companies, including 5 from Poland and 7 from Finland. The details about the investigated cases can be found in Table 2. The experts were asked two basic questions: 1) In your perspective, what are the major RET diffusion barriers in your country? and 2) What are the measures to overcome these barriers? It is important to note at this point that to assure the transparency and integrity of the study as well as to address the GDPR requirements, neither the companies' nor the interviewees' names will be revealed. This anonymity has been requested and agreed upon by both researchers and the respondents.

Table 2. Details about case companies.

\begin{tabular}{|c|c|c|c|}
\hline Company & Technology focus & Interviewee's role & Country \\
\hline A & $\begin{array}{l}\text { Automation \& electrification of wind } \\
\text { power }\end{array}$ & $\begin{array}{l}\text { Executive Vice President, Marketing \& } \\
\text { Sales }\end{array}$ & Finland \\
\hline B & $\begin{array}{l}\text { Energy technology hub; smart grids, en- } \\
\text { ergy efficiency, and marine solutions }\end{array}$ & Communications \& Brand Manager & Finland \\
\hline $\mathrm{C}$ & Wind and solar power & $\mathrm{CEO}$ & Finland \\
\hline $\mathrm{D}$ & Solar PV in the maritime sector & CEO & Finland \\
\hline $\mathrm{E}$ & Circular economy; waste to energy & CEO & Finland \\
\hline $\mathrm{F}$ & Wind power & Head of Project Development & Finland \\
\hline G & Wind power & Vice President, Energy Management & Finland \\
\hline $\mathrm{H}$ & Wind energy & Managing Director & Poland \\
\hline $\mathrm{I}$ & Solar energy & Operations Manager & Poland \\
\hline $\mathrm{J}$ & Solar PV inverters & Head of Marketing & Poland \\
\hline K & Energy from waste and biomass & CEO & Poland \\
\hline $\mathrm{L}$ & Biogas and biomethane & $\begin{array}{l}\text { 1) Managing Director } \\
\text { 2) An external expert from aca- } \\
\text { demia }\end{array}$ & Poland \\
\hline
\end{tabular}

To perform this comparative case study, we based on the policy, statistical and literature analysis. Energy policy review helped us in performing a thorough insight into the regulatory environment of the two investigated countries, including the governmental strategies for the future. It also provided us the national targets for including the renewables into total energy mixes, and consequently, conclusions from the results of the efforts to fulfill these goals. An analysis of widely available statistics has served us to identify the 
RES with the highest share in both countries, to focus mainly on the most common and/or most prosperous renewables in Finland and Poland. Furthermore, the synthesis of the most popular barriers presented in the literature review has been identified and structured, which has enabled us to create a categorization of barriers for our analysis. Next, we've compared and combined the barriers existing in the literature with the most commonly identified bottlenecks by our interviewees.

Such analysis, a cross-case comparative study, as in its genuine purpose, has served us in performing the extrapolation of the most critical barriers for RET diffusion in both countries. This comparison generates the possibility to draw insightful conclusions as well as to suggest practical and long-lasting measures for the betterment of the current state of affairs. Moreover, practices from the countries taken into scope may vary, which creates the capacity to transfer knowledge, technology, and managerial tools within these countries $[41,42]$.

\section{Results of the analyses}

As already mentioned before, in this study the main focus has been put on the regulatory and socio-economic issues of RET implementation in two European Union member states: Finland and Poland. To do so, it is necessary to analyze specific countrywide Renewable Energy Action Plans. These are the national policies aimed to address the legal commitments coming from the numerous regulations adopted by the international community. Since Finland and Poland are both EU countries, these obligations are coming namely from the Directive 2009/28/EC [43] which are, still, in line with the UN's and IPCC' $\mathrm{s}^{1}$ resolutions.

In Finland, the targeted RES share for 2020 has been elevated to $38 \%$. In the case of GHG emissions, the national target aimed at a 16\% decrease, compared to 2005 levels. What makes Finland a role model for the rest of Europe and the world, these targets have been reached already in 2014 [44]. New targets for 2030 are the following: 51\% RES share and 39\% GHG emissions reductions in comparison to 2005 realities. The government of Finland also declares the ambition to become carbon-neutral by 2035 and, consequently, to become the world's first fossil-free welfare society [45].

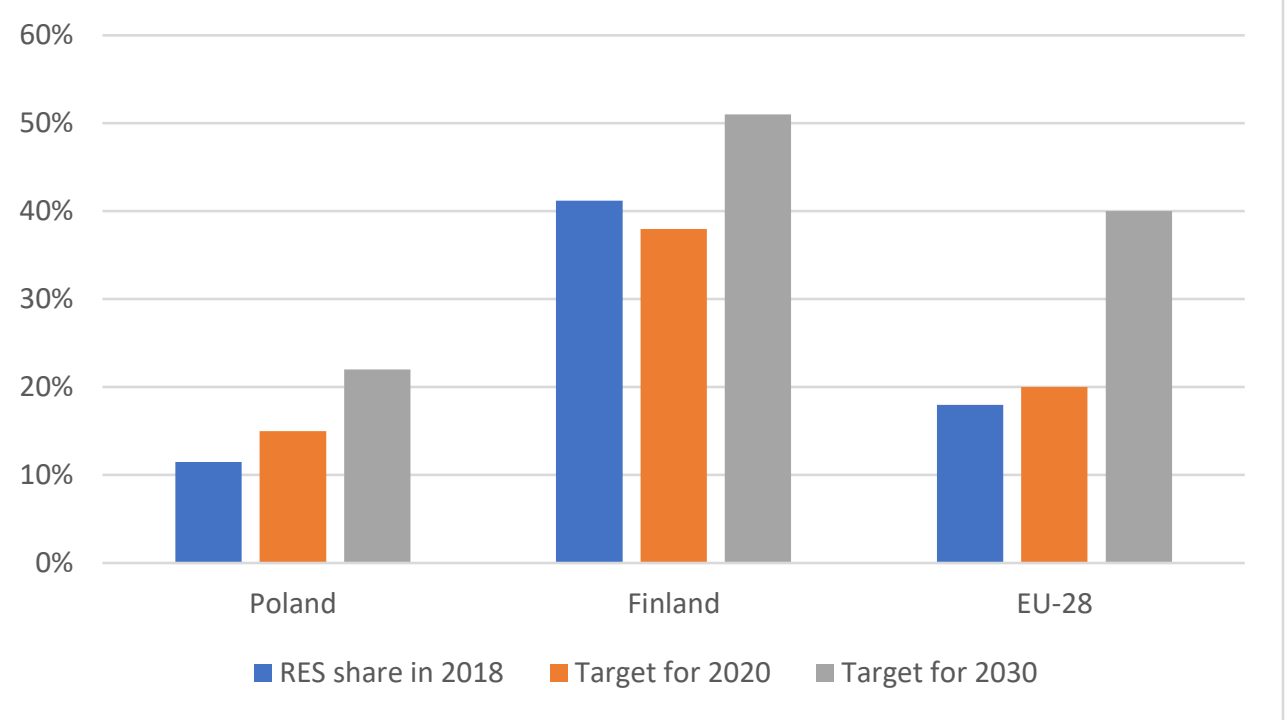

Figure 1. Share of renewables in final gross consumption. Own calculations based on [49].

\footnotetext{
1 The Intergovernmental Panel on Climate Change (IPCC) is the United Nations body for assessing the science related to climate change. It was created to provide policymakers with regular scientific assessments on climate change, its implications and potential future risks, as well as to put forward adaptation and mitigation options.
} 
In the Polish case, the goal for 2020 concerning the distribution of renewables in overall energy consumption has been limited to $15 \%$, and furthermore, the target of $10 \%$ share of biofuels in transport has been established [46,47]. It is important to note that despite these reductions, Poland failed to meet the previsioned targets [48]. New targets for 2030 aim at $21-23 \%$ RES share in gross final energy consumption, $14 \%$ of renewables in transport as well as 32\% RES share in electricity production. On the EU level, in 2018, 12 Member States met and exceeded the (2020) target for the share of renewable energy in gross final energy consumption. The remaining 16 countries have yet to reach their target [49]. Figure 1 shows the effectiveness in reaching the renewable energy targets in Finland, Poland, and the whole EU-28.

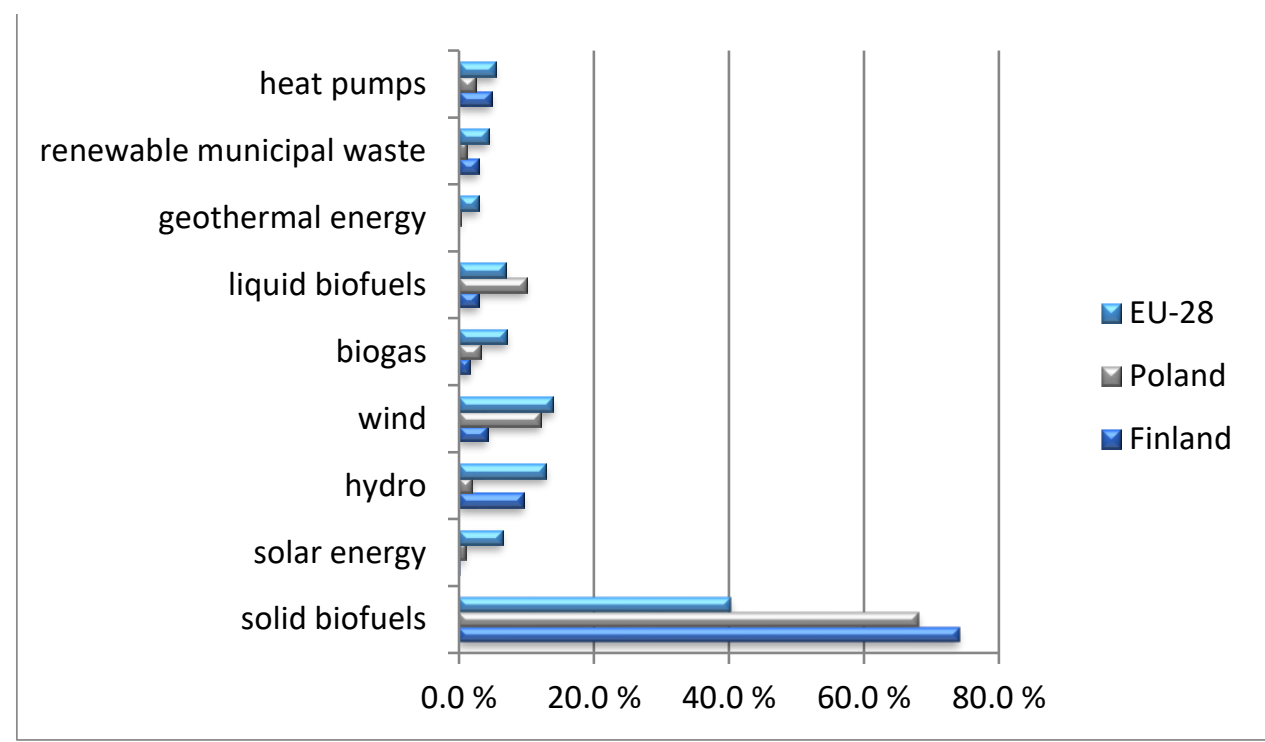

Figure 2. The structure of energy production from renewables in 2018. Own calculations based on [49].

As can be concluded from Figure 2, solid biofuels were the principal type of renewables in the total energy generation (for electricity, heating, and transport determinations) in the whole EU-28 in 2018. In energy statistics, they are defined as the "product aggregate equal to the sum of charcoal, fuelwood, wood residues, and by-products, black liquor, bagasse, animal waste, other vegetal materials and residuals and the renewable fraction of industrial waste", whereas liquid biofuels refer to "the sum of bio-gasoline, biodiesels, bio-jet kerosene and other liquid biofuels" [50]. Both Finland and Poland are characterized by the richness of forestry and agricultural areas, therefore wood fuels and biomass lead the way in these countries. However, in terms of electricity production, which has the most share in case of the energy use, as well as commercial applications, other types of renewables take the leading role. In Finland, the share of renewables in electricity generation in 2020 amounted to 52\%, with hydro (45\%), black liquor (17\%), wind (23\%), and other wood fuels (12\%) [51]. In Poland, wind energy was the main RET in terms of electricity generation in 2018 with a $58 \%$ share, followed by solid biofuels (24\%), hydro (11\%), and biogas (over 5\%) [49].

\subsection{Categories of barriers for RET diffusion in Finland and Poland}

As already shown, the literature analysis provides different types of challenges for a successful RET adoption in the investigated countries. For example, Salmela examined the non-environmental issues from the Finnish electricity customers' perspective and they have recognized three categories: cognitive, associated with the lack of trust and technological know-how; orientational, related to time and efforts put into former customer behaviors or priorities; and economic, linked with relatively higher initial costs [29]. Furthermore, Aslani considered the potential for various RET development in Finland, and came up with joint barriers and they fall under three following categories: policy, 
environment, and cost [5]. Moreover, Kangas studied energy efficiency-related barriers in Finland from the viewpoint of energy companies, and concluded with such factors as unsatisfactory level of technological skills, ineffective regulations, and imperfections in the information stream as main difficulties [52].

In Poland, major bottlenecks identified in the literature are supporting the mainstream barrier of ineffective regulatory frameworks, mainly by underlining the excessiveness or insufficiency of the current policy support schemes. For instance, the most recent study on this topic by Brauers focuses on the political implications of the Polish coal-based energy mix and identifies major challenges linked with this issue, and these are generally: economic, political \& legislative, and social \& environmental factors [7]. Within the first category, the most critical constraints are the regional economic dependency of the Silesia region associated with the high employment rate in the mining sector, limited financial schemes to support renewables as well as relatively high electricity prices for households in the short-term perspective. Under the second category, they identify energy security consternation, but more importantly the political influence of the coal industry and its labor unions. The last category is related to the past geopolitical experiences, which imply a threat of such disruptive change within the society and a lack of eagerness to resign from coal as a source of the country's further development. Furthermore, Paska and Surma examined different national energy policies aiming at enhancing RET development as well as to fulfill the international emission targets. The study identifies the main challenges for the Polish energy sector, i.e. limited domestic fuel demand and energy generation capacity or distribution infrastructure as well as heavy dependence on an external supply of energy from natural gas and crude oil. After concluding that renewables can play a significant role in overcoming many of these obstacles, they have found numerous negative implications associated with the current policy schemes, e.g. green energy certificates mechanisms generating more costs for the end-customers of electricity, lack of long-term vision from the government, resulting in instability and unreliability of the regulatory environment, or ineffective grid development [47]. Similarly, Dolega found out namely legal/formal and technical barriers for the further RET development in Poland, and these are e.g. restrictive auction parameters, the complexity of processes of receiving permits for technology installations, general bureaucratization and lengthiness of administrative procedures, instability, and unclarity of the legal framework, lack of long-lasting financial support mechanisms, or insufficient grid infrastructure [53]. Moreover, in their case study among the renewable energy industry experts, Pietrzak et al. determined the most hampering factors for RET diffusion in Poland, starting with the strongly unfavorable influence of the coal-centered energy lobby as well as complex and unclear energy regulations as the aspects with the most impact [54]. The experts also outlined relatively high entry cost barriers of investments, unsatisfactory level of societal technology knowledge, or low and unstable green certificates prices. These numerous issues raised by the studies mentioned in this section act as a theoretical and practical foundation for this study, as the most common challenges in RET adoption in Finland and Poland can be put into categories to present the results of the central analysis in a well-organized way. Table 3 presents the categories of barriers for RET diffusion in Finland and Poland identified in the literature.

Table 3. Categories of RET barriers in Finland and Poland.

\begin{tabular}{lll}
\hline Category & Examples & Reference \\
\hline & Lack of financing options, high initial costs, market uncertainty, & $5,7,10,17,25$, \\
Economic \& Market & $\begin{array}{l}\text { long payback time, investment risk, dependency on energy exports } \\
29,48\end{array}$ & \\
\hline
\end{tabular}


Ineffective and unstable policies, excessive and complex proce-

Political \& Regulatory dures, favoring big, state-owned companies or conventional energy sources
$5,7,39,47,48$, $52,53,54$
Societal

Technical
Lack of know-how, information issues, reluctance to change, NIMBYism

Ineffective grid development, insufficient or obsolete infrastructure
$7,29,47,48,52$

$10,17,25,47$, 53

Additionally, the main author of this research presented the comparison of RET diffusion barriers in Poland and Finland, based mainly on the literature review and statistical analysis. In fact, this study acts as specific development of the author's research project through the support of the empirical evidence from the renewable energy industry [48].

\subsection{Main RET diffusion barriers from the industry experts' perspective}

Our analysis supports and underlines the barriers already commonly identified in the literature as well as adds some new insight on specific bottlenecks that can be included in these broad categories. We also provide the measures that in our interviewees' opinion might improve the current state of affairs in both countries. It is also important to note that in the case of two Finnish companies, their executives could not specify any critical barriers for the RET diffusion as they perceived the country's current business environment highly supportive. Still, they were able to suggest some steps aimed at further improvement of certain conditions.

Finnish experts agreed that 'when it comes to energy, there's always politics involved', which can have either a beneficial or unfavorable effect. Among the latter ones, our respondents were usually raising the issue of unstable, disorienting, and risk-generating regulations. They have experienced some major alterations, e.g. coming from the changes in the government that have caused many challenges for their companies. Moreover, there are numerous environmental, economic, or technical criteria to fulfill, and 'getting these permits can last forever', which can result in e.g. selling pilot projects abroad, where such innovative solutions can prosper more freely. Another important issue outlined was the lack of support schemes for SMEs and start-ups focused on renewables, expressed mainly by limited financing - and consequently - commercialization opportunities. This may be due to the fact that 'it's a rather conservative industry, and it takes about 2-3 years to get your technology introduced in the market'. Moreover, Finnish RET companies' executives mentioned some technological issues, like the need for more efficient energy transfer solutions or the necessity to maintain sufficient levels of technological know-how to keep up with current changes of the customer needs; as well as some socio-economic constraints, such as the higher initial cost for the renewables, compared to conventional solutions, or the phenomenon called 'NIMBYism', which stands for Not-In-My-Backyard, a societal reserve and reluctance to constructing some landscape-influencing and noise-generating wind parks or foul-smelling biogas plants in their close neighborhoods [55].

Similarly, Polish experts have found a coal-centered and highly politicized energy sector as a central barrier for the enhanced prosperity of renewables in that country. The main objection to the government's actions is that 'despite many promises to follow the international goals, there is still a strong coal lobby (companies and labor unions) and thus, the government is far away from giving up on coal-based energy economy', and this lobby creates a 'fear effect of massive protests and a huge societal challenge how to perform this transition without a 
harm for the occupational groups from the mining sector'. Moreover, the current national regulatory frameworks are not necessarily considered as supportive or providing stability. The authorities tend to support rather fossil fuel companies with numerous subsidies or bailing-out of bankrupt coal companies than opting for renewable energy technologies, 'which seems to be both unreasonable and irresponsible for our future'. Furthermore, various socio-economic constraints, our interviewees stressed out so-called 'willingness-to-pay' aspects, which in their negative aspect is a hesitancy to initially pay more for the energy generated from renewables, compared to the cost of the conventionally produced energy. In its economic simplicity, 'cost is always seen as a possible barrier' both for the companies providing green energy as well as for the end-customers. Another important issue is the societal reluctance to change the current situation, which is supported by the 'beliefs that coal is critical for Polish further economic prosperity and it should be protected by the government'. This, in consequence, provokes a lack of interest in investing in RETs or nuclear power plants, which would significantly increase the level of Polish energy security, e.g. by decreasing the dependency on fossil fuels and energy imports (mainly in case of the Russian gas). Lastly, some public protests have been noted in response to the plans of biogas plants or wind power parks installments next to the inhabited areas, which is a clear example of the aforementioned 'NIMBYism'.

\section{Conclusions and suggestions towards improvement}

The most appealing conclusion of this study is that despite relatively huge societal, environmental, or economic differences between Poland in Finland, these countries share the major barriers perceived by their energy industry experts. In both countries, it was the political sector that appeared to have the most possibly negative impact on the renewable energy industry. The current policy schemes were estimated as insufficient in terms of support provided by the government or excessive when it comes to the complexity of the legal and formal procedures. In plus, systematic changes in the regulatory frameworks have been seen as a destabilizing factor generating high-risk levels. Such a comparative analysis of the conditions for RET development in these two specific European countries provides novel implications for the interest groups coming from the energy sector.

The analysis also shows that there are similarities between the investigated case countries in the category of socio-economic aspects. Even though the level of societal awareness is significantly higher in Finland, there were several common barriers identified by the case companies' executives, such as: high initial investment and transaction costs, doubts about the RET efficiency and reliability as well as strictly community-based issues like NIMBYism or unwillingness to pay more for the environmentally-friendly solutions. Moreover, the commercialization challenges are common within various technology-oriented SMEs and start-ups across the globe, hence it was expected to detect such kinds of issues through this analysis.

There are, however, some differences between various case companies from both countries. Firstly, there have been two managers from Finland (companies D\&F) who could not determine any critical policy or socio-economic barrier for their firms' further development. In their perspective, the conditions for developing RET are highly favorable. It was in fact often the case in the Finnish side of the research that experts needed more time to think about possible barriers, as they have mostly underlined the benefits of being located and operating in Finland. However, the most common issue expressed by the interviewees was the insufficient support for RET start-ups and SMEs. Since such business initiatives focus primarily on the technology development aspects, they often lack financial and managerial resources that would enhance their commercialization. It has also been seen as a regulatory barrier, as 'government supports the big companies instead of small players, and it's not as much entrepreneurial-driven as it should be'. Polish experts also numerously raised this bottleneck, mainly due to the fact that conventional energy companies are more often than not huge, state-owned corporations. Therefore, they receive more financial and regulatory support than smaller-sized innovative technology ventures. 
However, the main difference between Finland and Poland was found in the regulatory/policy support for the RET. In Poland, our interviewees firmly underlined the fact of the politically-related energy sector, which is currently oriented towards fossil fuels such as coal and lignite. This significantly reduces the potential for the RET diffusion, by e.g. 'favoring the mining sector, mainly because of the social pressure', which results in 'simply leaving less market share for such energy sources'.

To address these numerous barriers, our respondents were also asked to provide solutions for the betterment of the current state of affairs in their countries. In Finland, where the most critical issue is the technology commercialization aspect, there have been numerous wishful recommendations for the Finnish government to become 'more entrepreneurialdriven' and to enhance more emerging sustainable solutions. Under this rather universal suggestion, the experts expect that the procedures of acquiring necessary financial support, collecting feed-in-tariffs, green certificates, or getting legal permits for starting the operations would be 'less challenging, much faster and more simplified'. This kind of more specialized support would create the 'positive push' from the government to develop new technologies by the SMEs and start-ups, which are now dominated by big-sized companies, which 'would have that money anyway'. Moreover, some of our respondents expressed the will to intensify the cooperation and contacts with the customers, to 'listen and respond to their needs'. This would perhaps boost the levels of customer satisfaction and their willingness to adopt more sustainable solutions, which in consequence, could critically enhance the RET diffusion in general. Furthermore, in the case of wind power companies, experts - perceiving the landscape-disturbing nature of the wind parks - would appreciate 'more efficient ways to use less land for wind energy generation', taking environmental impacts of such technologies into account more appropriately.

The improvement suggestions from the Polish renewable energy sector representatives concerned primarily the most challenging issue of the coal-centered energy policy. First and foremost, there is a need to develop a long-run strategy to enhance more renewables into the system, followed by tangible outcomes and actions from the government. For instance, some immediate actions are expected, with the caveat of their political feasibility, such as dramatically reducing financial support for the mining industry, which is already in a bad economic situation, or imposing energy diversification obligations on the energy companies. Moreover, more supportive regulations could lead to improvement in terms of energy security, independence of energy imports, or competitiveness of the Polish economy and they could be aimed at e.g. investing more in state-owned renewable energy companies, developing more financial and socio-economic incentives mechanisms, etc. The current Polish energy sector is 'overly influenced by the politicians and labor unions', therefore a realistic restructuration plan would have to carefully take the coal industry interests into account, by providing beneficial alternatives, such as e.g. new work opportunities, long-perspective -'evolution rather than revolution' approach - transition period, or more efficient use of financial capital. There have been some successful examples of the swift and effective energy transition processes e.g. in Germany, where the project called Energiewende relies heavily on renewables and its positive effects can be clearly noticed, which makes it a relevant case to follow [56].

This study also presents collective and universal recommendations for the RET companies and other interest groups associated within the renewable energy industry both from Finland and Poland or perhaps from the whole EU. Firstly, it is in common sense for the EU member states to follow the regulations aiming at further RET development. For instance, the 'European Green Deal' [57] or 'Fit for 55' [58] strategies can act as effective multidimensional (but mostly financial) incentives for the EU countries to strengthen their efforts to become carbon-neutral in the future perspective. This can result in numerous benefits for both countries, e.g. using this situation to modernize obsolete grid installations which would enhance the novel, renewables-fitted infrastructural solutions as well as provide more energy security and efficiency. Another highly important hindrance to challenge is the insufficient levels of: technology know-how, information about the economic and environmental impact, and, consequently, support for renewables within the 
different sectors of society. This issue can be addressed by multidimensional awarenessraising actions, such as professional training, specialized conferences, business incubator programs, activist movements, or impactful media communications, just to mention a few possibly favorable measures. Furthermore, high-tech SMEs and start-ups (including RETfocused ones), which are often struggled with the lack of financial and managerial resources, should consider external funding options other than the EU subsidies, such as business angels or venture capitals (VC). Numerous studies support the claim that especially VC, in addition to the strictly financial contribution, can add value to their portfolio companies through providing e.g. corporate governance excellence, business networks and internationalization options, legitimization, managerial expertise, etc. [59,60]. Lastly, it is critical to follow the fast-paced technological development of the energy sector, according to the so-called 'Energy 3Ds', which stands for decarbonization, decentralization, and digitalization [61,62]. This can be achieved by, inter alia, smart grid investments, or deployment of IoT and Blockchain for renewable energy [63-66]. It is forecasted that such innovative technologies would revolutionize the energy supply chains by removing the intermediaries from the transaction processes, providing more transparency, integrity, and security, as well as developing energy trading platforms, or automating the issuance of the green certificates, etc. [67]. However, blockchain technology is still in its infancy stage as there is no widespread supportive regulatory framework for such solutions yet.

Author Contributions: Conceptualization, O.J., and J.T.; methodology, O.J.; validation, S.J., J.T., and O.J.; formal analysis, S.J., and J.T.; investigation, O.J., and J.J.; resources, O.J., J.J. and S.J.; data curation, O.J.; writing - original draft preparation, O.J.; writing - review and editing, O.J., J.J. and S.J.; visualization, O.J., S.J., and J.J.; supervision, J.T., and S.J.; project administration, O.J., S.J., and J.T. All authors have read and agreed to the published version of the manuscript.

Funding: This research received no external funding.

Conflicts of Interest: The authors declare no conflict of interest.

\section{Abbreviations}

$\begin{array}{ll}\text { RET } & \text { Renewable Energy Technologies } \\ \text { R\&D } & \text { Research and Development } \\ \text { GDP } & \text { Gross Domestic Product } \\ \text { Solar PV } & \text { Solar Photovoltaics } \\ \text { UN } & \text { United Nations } \\ \text { GHG } & \text { Greenhouse gases } \\ \text { TAM } & \text { Technology Acceptance Model } \\ \text { GDPR } & \text { General Data Protection Regulation } \\ \text { RES } & \text { Renewable Energy Sources } \\ \text { CEO } & \text { Chief Executive Officer } \\ \text { EU } & \text { European Union } \\ \text { IPCC } & \text { Intergovernmental Panel on Climate Change } \\ \text { SMEs } & \text { Small and Medium Enterprises } \\ \text { VC } & \text { Venture Capital }\end{array}$

\section{References}

1. Al-Ghussain, L.: Global warming: review on driving forces and mitigation. Environmental Progress \& Sustainable Energy, 38(1), pp. 13-21. (2019).

2. Arent, D. J., Wise, A., \& Gelman, R.: The status and prospects of renewable energy for combating global warming. Energy Economics, 33(4), pp. 584-593. (2011).

3. Sáez-Martínez, F. J., Lefebvre, G., Hernández, J. J., \& Clark, J. H.: Drivers of sustainable cleaner production and sustainable energy options. J. Clean. Prod., 138, pp. 1-7. (2016).

4. World Intellectual Property Organization (WIPO). Global Innovation Index: Finland, 2020. https://www.wipo.int/edocs/pubdocs/en/wipo_pub_gii_2020/fi.pdf 
5. Aslani, A., Naaranoja, M., Helo, P., Antila, E., \& Hiltunen, E.: Energy diversification in Finland: achievements and potential of renewable energy development. International journal of sustainable energy, 32(5), pp. 504-514. (2013).

6. Sokka, L., Sinkko, T., Holma, A., Manninen, K., Pasanen, K., Rantala, M., \& Leskinen, P.: Environmental impacts of the national renewable energy targets-A case study from Finland. Renewable and Sustainable Energy Reviews, 59, pp. 15991610. (2016).

7. Brauers, H., \& Oei, P. Y.: The political economy of coal in Poland: Drivers and barriers for a shift away from fossil fuels. Energy Policy, 144, 111621. (2020).

8. Hernik, J., Noszczyk, T., \& Rutkowska, A.: Towards a better understanding of the variables that influence renewable energy sources in eastern Poland. Journal of Cleaner Production, 241, 118075. (2019).

9. Wilson, C.: Disruptive low-carbon innovations. Energy Research \& Social Science, 37, 216-223. (2018).

10. Shakeel, S. R., Takala, J., \& Zhu, L. D.: Commercialization of renewable energy technologies: A ladder building approach. Renewable and Sustainable Energy Reviews, 78, 855-867. (2017).

11. Lund, P. D.: Effects of energy policies on industry expansion in renewable energy. Renewable energy, 34(1), pp. 53-64. (2009).

12. Blok, K.: Renewable energy policies in the European Union. Energy policy, 34(3), pp. 251-255. (2006).

13. United Nations Framework Convention on Climate Change (UNFCCC): Paris Agreement, https://unfccc.int/resource/docs/2015/cop21/eng/10a01.pdf, (2016).

14. EC: GREEN PAPER A 2030 framework for climate and energy policies, https://eur-lex.europa.eu/legal-content/EN/TXT/?uri=CELEX:52013DC0169, (2013).

15. EC: A Clean Planet for all, A European strategic long-term vision for a prosperous, modern, competitive and climate neutral economy, COM/2018/773 final, https://eur-lex.europa.eu/legal-content/EN/TXT/?uri=CELEX:52018DC0773, (2018).

16. Jacobsson, S., \& Johnson, A.: The diffusion of renewable energy technology: an analytical framework and key issues for research. Energy policy, 28(9), pp. 625-640. (2000).

17. Peura, P., Haapanen, A., Reini, K., \& Törmä, H.: Regional impacts of sustainable energy in western Finland. Journal of Cleaner Production, 187, pp. 85-97. (2018).

18. Horbach, J., Rammer, C., \& Rennings, K.: Determinants of eco-innovations by type of environmental impact-The role of regulatory push/pull, technology push and market pull. Ecological economics, 78, pp. 112-122. (2012).

19. Elkington, J.B.: Cannibals with Forks: The Triple Bottom Line of 21st Century Business. Capstone Publishing, Oxford. (1997).

20. Gimenez, C., Sierra, V., \& Rodon, J.: Sustainable operations: Their impact on the triple bottom line. International Journal of Production Economics, 140(1), pp. 149-159. (2012).

21. Owen, A. D.: Renewable energy: Externality costs as market barriers. Energy Policy, 34(5), pp. 632-642. (2006).

22. Davis, F.D. Perceived usefulness, perceived ease of use, and user acceptance of information technology. MIS quarterly, pp. 319-340. (1989).

23. Pietruszko, S. M.: The status and prospects of photovoltaics in Poland. Renew energy, 16(1-4), pp. 1210-1215. (1999).

24. Budzianowski, W. M.: Sustainable biogas energy in Poland: Prospects and challenges. Renew Sust Ener Rev, 16(1), pp. 342349, (2012).

25. Piwowar, A., Dzikuć, M., \& Adamczyk, J.: Agricultural biogas plants in Poland-selected technological, market and environmental aspects. Renew Sust Ener Rev, 58, pp. 69-74. (2016).

26. Winquist, E., Rikkonen, P., Pyysiäinen, J., \& Varho, V.: Is biogas an energy or a sustainability product? -Business opportunities in the Finnish biogas branch. J. Clean. Prod., 233, pp. 1344-1354. (2019).

27. Niemi, R., Mikkola, J., \& Lund, P. D.: Urban energy systems with smart multi-carrier energy networks and renewable energy generation. Renew Energy, 48, pp. 524-536. (2012).

28. Möllerström, E.: Wind turbines from the Swedish Wind energy program and the subsequent commercialization attempts A historical review. Energies, 12(4), 690. (2019).

29. Salmela, S., \& Varho, V.: Consumers in the green electricity market in Finland. Energy policy, 34(18), pp. 3669-3683. (2006).

30. Tapaninen, A., Seppänen, M., \& Mäkinen, S.: Characteristics of innovation: a customer-centric view of barriers to the adoption of a renewable energy system. International Journal of Agile Systems and Management 4, pp. 98-113, (2009).

31. Dinica, V.: Support systems for the diffusion of renewable energy technologies - an investor perspective. Energy policy, 34(4), pp. 461-480. (2006).

32. Lucchi, E., Polo Lopez, C.P., \& Franco, G.: A conceptual framework on the integration of solar energy systems in heritage sites and buildings. IOP Conf. Ser.: Mater. Sci. Eng. 949 012113, (2020).

33. Ruggiero, S., Onkila, T., \& Kuittinen, V.: Realizing the social acceptance of community renewable energy: A process-outcome analysis of stakeholder influence. Energy Res. Soc. Sci, 4, pp. 53-63. (2014).

34. Jung, N., Moula, M. E., Fang, T., Hamdy, M., \& Lahdelma, R.: Social acceptance of renewable energy technologies for buildings in the Helsinki Metropolitan Area of Fin-land. Renew. Energy, 99, pp. 813-824. (2016).

35. Popp, D., Hascic, I., \& Medhi, N.: Technology and the diffusion of renewable energy. Energy Econ, 33(4), pp. 648-662. (2011).

36. Tsoutsos, T. D., \& Stamboulis, Y. A.: The sustainable diffusion of renewable energy technologies as an example of an innovation-focused policy. Technovation, 25(7), pp. 753-761. (2005). 
37. Kitzing, L., Mitchell, C., \& Morthorst, P. E.: Renewable energy policies in Europe: Converging or diverging? Energy policy, 51, pp. 192-201. (2012).

38. Monni, S., \& Raes, F.: Multilevel climate policy: the case of the European Union, Finland and Helsinki. Environ Sci Policy, 11(8), pp. 743-755. (2008).

39. Aslani, A., Helo, P., \& Naaranoja, M.: Role of renewable energy policies in energy dependency in Finland: System dynamics approach. Applied energy, 113, pp. 758-765. (2014).

40. Beck, F., Martinot, E.: Renewable energy policies and barriers, Cutler Cleveland (Ed.), Encyclopedia of energy, Academic Press/Elsevier Science, San Diego, pp. 365-383, (2004)

41. Rihoux, B., \& Ragin, C. C.: Configurational comparative methods: Qualitative comparative analysis (QCA) and related techniques. Sage Publications. (2008).

42. Rogers, E. M., Takegami, S., \& Yin, J.: Lessons learned about technology transfer. Technovation, 21(4), pp. 253-261. (2001).

43. EU. Directive 2009/28/EC of the European Parliament and of the Council of 23 April 2009 on the promotion of the use of energy from renewable sources and amending and subsequently repealing Directives 2001/77/EC and 2003/30/EC. Official Journal of the European Union, 2009, 5: 2009.

44. EC. Europe 2020 targets: statistics and indicators for Finland, https://ec.europa.eu/, (2019).

45. FI. Ministry of Economic Affairs and Employment. "Finland's Integrated Energy and Climate Plan." (2019).

46. National Renewable Energy Action Plan. Polish Ministry of Economy. Warsaw, (2010). Retrieved from https://ec.europa.eu/energy/en/topics/renewable-energy/national-renewable-energy-action-plans-2020\#forecasts, 3.11.2021.

47. Paska, J., \& Surma, T.: Electricity generation from renewable energy sources in Poland. Renew Energy, 71, pp. 286-294. (2014).

48. Juszczyk, O.; Shakeel, S.R.: Comparative Analysis of Barriers for Renewable Energy Technologies Diffusion in Finland and Poland. International Conference on Applied Human Factors and Ergonomics. Springer, Cham, (2020).

49. Statistics Poland (GUS). Energy from renewable sources in 2019. Statistical analyses. Warsaw, 2020. ISSN: 1898-43479, retrieved online on 11.11.2021.

50. Eurostat: Statistics explained, Glossary: Biofuels, ISSN 2443-8219 https://ec.europa.eu/eurostat/statistics-explained/index.php/Glossary:Biofuels. (2019).

51. Official Statistics of Finland (OSF): Production of electricity and heat [e-publication]. ISSN=1798-5099. 2020, Appendix figure 2. Electricity generation with renewables 2020. Helsinki: Statistics Finland [referred: 11.11.2021]. Access method: http://www.stat.fi/til/salatuo/2020/salatuo_2020_2021-11-02_kuv_002_en.html.

52. Kangas, H. L., Lazarevic, D., \& Kivimaa, P.: Technical skills, disinterest and non-functional regulation: Barriers to building energy efficiency in Finland viewed by energy service companies. Energy Policy, 114, pp. 63-76. (2018).

53. Dolega, W.: Problems, barriers and perspectives of RES development in Poland. Engineering and Industry, 3. (2016).

54. Pietrzak, M.B.; Igliński, B.; Kujawski, W.; Iwański P.: Energy Transition in Poland - Assessment of Renewable Energy Sector. Energies 2021, 14, 2046. https://doi.org/10.3390/en14082046.

55. Pelham, B. W.: Not in my back yard: Egocentrism and climate change skepticism across the globe. Environ Sci Policy, 89, pp. 421-429. (2018).

56. Hake, J. F., Fischer, W., Venghaus, S., \& Weckenbrock, C.: The German Energiewende-history and status quo. Energy, 92, pp. 532-546. (2015).

57. EC: The European Green Deal. COM/2019/640 final. https://eur-lex.europa.eu/legal-content/EN/TXT/?uri=CELEX:52019DC0640.

58. EC: 'Fit for 55': delivering the EU's 2030 Climate Target on the way to climate neutrality. COM/2021/550 final. https://eurlex.europa.eu/legal-content/EN/TXT/?uri=CELEX\%3A52021DC0550.

59. Shakeel, S.R., Juszczyk, O.: The Role of Venture Capital in the Commercialization of Cleantech Companies. Management 14(4), pp. 325-339. (2019). DOI: 10.26493/1854-4231.14.325-339.

60. Moore, B., \& Wüstenhagen, R.: Innovative and sustainable energy technologies: the role of venture capital. Business Strategy and the Environment, 13(4), pp. 235-245. (2004).

61. Di Silvestre, M. L., Favuzza, S., Sanseverino, E. R., \& Zizzo, G.: How Decarbonization, Digitalization and Decentralization are changing key power infrastructures. Renewable and Sustainable Energy Reviews, 93, pp. 483-498. (2018).

62. Morell Dameto, N., Chaves-Ávila, J. P., \& Gómez San Román, T.: Revisiting electricity network tariffs in a context of decarbonization, digitalization, and decentralization. Energies, 13(12), 3111. (2021).

63. Ardito, L., Procaccianti, G., Menga, G., \& Morisio, M.: Smart grid technologies in Europe: An overview. Energies, 6(1), 251281. (2013).

64. Hafeez, S., Juszczyk, O., \& Takala, J.: A Roadmap for successful IoT implementation: empirical evidence from the energy industry. Issues in Information Systems, 22(1). (2021).

65. Hossein Motlagh, N., Mohammadrezaei, M., Hunt, J., \& Zakeri, B.: Internet of Things (IoT) and the energy sector. Energies, 13(2), 494. (2020).

66. Kim, S. K., \& Huh, J. H.: A study on the improvement of smart grid security performance and blockchain smart grid perspective. Energies, 11(8), 1973. (2018).

67. Andoni, M., Robu, V., Flynn, D., Abram, S., Geach, D., Jenkins, D., ... \& Peacock, A.: Blockchain technology in the energy sector: A systematic review of challenges and opportunities. Renewable and Sustainable Energy Reviews, 100, pp. 143-174. (2019). 